\title{
A Preliminary Bulletin on Some Economic Insects and Plant Diseases of Indiana
}

SB 824

. I6 A5 1907 Copy 1

BENJAMIN W. DOUGLASS .

State Entomologist

INDIANAPOLIS, INDIANA

1907 



\section{A PRELIMINARY BULLETIN}

ON

\section{Some Economic Insects and Plant Diseases of Indiana}

Benjamin W. Douglass

State Entomologist

INDIANAPOLIS, INDIANA

\section{7}




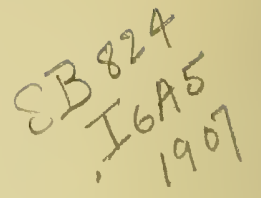

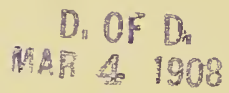

$\because \vdots \vdots$ 


\section{Some Economic Insects and Plant Diseases of Indiana}

\section{OfFice of the State Entolrologist}

BENJA MIN W. DOUGLASS

It has been claimed by eminent scientists that all the diseases of men common in Indiana, even to the notorions malaria of the swamps, were brought into this territory by the people who eame from the older settlements. A similar statement would hold true for most of the insect and fungus parasites that infest the plants of the State. It has not been such a long time since it was possible to grow fruit of all kinds and have a large percentage of perfect specimens in the harvest.

Today, however, there have been so many injurious insects introduced and so many fungus enemies have made their appearance that the problem of the horticulturist and the agriculturist is a great one, and one that will tend to increase instead of decrease as time goes on. Today the fruit grower, even though he has but a few trees or berry bushes, must own a spray pump of some sort, and he must exercise a great deal of judgment in its use. Spraying has been played up for so many things that the novice is apt to be misled into thinking that it is a panacea for all orchard troubles, when, as a matter of fact, it is worthless unless done intelligently and with a proper regard for the requirements of the particular trouble involved. Before you start to spray be sure that you know what you are spraying for, and try to learn the best time to apply the proper spray or poison, and learn what that poison should be.

We may divide the things that it is necessary to spray for into three general groups, each group requiring special treatment.

\section{First Group-Biting or Chewing Insects.}

This class ineludes all of the more common larval forms which damage the plant by actually eating the tissues. They may best be handled by an internal poison placed on the leaves or other plant parts that they damage. Of such poisous Paris Green is 
the most commonly used and is, perhaps, one of the best. Examples of this group are the tomato worms, codling moths, elmleaf beetles, etc.

\section{Second Group-Sucking Insects.}

Insects of this elass damage the plants by inserting their mouth parts through the epidermis and securing their nourishment directly from the interior of the plant. They can not be reached by any poison such as would kill the chewing insects, but must be treated with a remedy strong enough to kill them by direct contact. This fact makes the sucking insect an especially hard class to fight, as many of the things used to destroy them are apt to damage the plant as well. For this class of insects the most common remedies are Coal-oil Emulsion, Whale-oil or other soap, strong tobaceo juice, and the Lime-Sulphur-Salt wash. The San Jose and other scales and the plant lice are examples of this class of insects.

\section{Third Group-Fungus Enemies.}

There are almost innumerable parasitic fungi that infest wild and eultivated plants, and often they become a very serious pest and do tremendous damage. They consist of small, often microscopic, plant bodies, which live in the body of the "host" plant, as it is called, and gradually cause its death, either by the destruction of the tissues or by the production of a direct poison.

The universal remedy for all such fungi is a solution of copper sulphate, either pure or with the addition of a certain percentage of lime, to neutralize the free acid of the sulphate and thus prevent damage to the leaves of the plant.

Then there is another group composed of both the plant and animal parasites, for which there is but little that can be done. Among these are the black knot on the cherry and the plum, and the blight in the pear, and the various kinds of borers that affect the boies of trees. While we know what the latter are, we have not ready means of combating them without destroying the trees. There are many problems that will come under this latter elass, and each requires individual study to develop the point at which it may best be attacked. For the most part, however, the problems that confront the farmer and tree grower of any sort can be found under one of the three first heads given, and the whole secret in the successful treatment of plant parasites is to be sure of what you want to do and then do it thoroughly. 


\section{INSECTICIDES}

\section{For the First Group-Biting Insects.}

The best poison to employ for this class is undoubtedly Paris Green, as it is easily prepared and is cheap, and its presence can usually be detected owing to its color, thus preventing it being taken for any other substance, as it is very poisonous. It is an arsenic preparation, and when used in solution must be constantly stirred to prevent settling, as it is heavy and settles rapidly. It is often advisable to add a bit of lime to the Paris Green solution to prevent any damage to the foliage which might result if it were used pure. On ordinary foliage, however, it is not necessary to use this precaution, as it is not probable that any harm will result from the use of the poison. It can be safely used in the proportion of one pound to one hundred and fifty gallons of water, and this proportion will prove effective for most purposes.

Other arsenical poisons are not mentioned here owing to the lack of space and because none of them are any better than Paris Green and a discussion of them might tend only to confuse the intending sprayer.

\section{For the Second Group-Sucking Insects. .}

This class of insects is a very hard one to reach by any method of spraying, and a great many different preparations have been tried from time to time, but with variable results. What has proved successful in one locality has, for one reason or another, entirely failed when applied by other experimenters at other places. The advent of the San .Jose scale and the increasing numbers of the various species of plant lice have made spraying with contact poisons a rather recent development in agricultural practice, and today it is far from being an exact science. Any poison for this class of insects must be strong enough to kill the insect by contact and still do no damage to the tree, and this result is sometimes hard to obtain. We can not devote any time to a review of the experiments that have been carried on in various parts of the country for some time, but simply give the formulas of some of the preparations that have in some localities been found effective. Probably any of them will prove 
effective and harmless to the tree if properly made and carefully applied. In no ease should any spraying solution be so lavishly applied that the ree drips. It will require practice to develop sufficient skill to spray a tree just enough, that is, until it is completely coated with the solution and no more.

\section{IIME-SULPHUR-SALT WASH.}

The following formula is one that is recognized and recommended by the foremost economic entomologists in the country, but it may be varied considerably without apparently detracting from its efficiency.

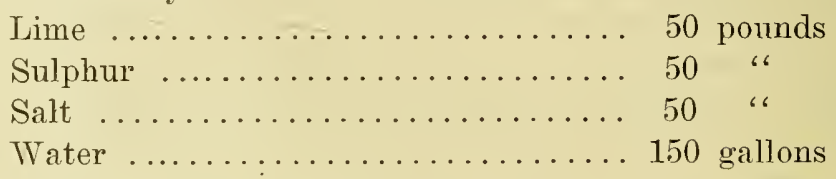

Add enough water to the lime to slake it thoroughly and im- . mediately add the sulphur. Boil for an hour or so with only water enough to keep the mass liquid, until the solution becomes a deep amber color. Have the salt dissolved in water and add it to the boiling mass. After it has all been mixed together, boil for at least another hour and then add water enough to make up the one hundred and fifty gallons, and spray it as soon as possible. It is more efficient when used warm, and some of the failures with this wash have undoubtedly been due to the use of stale solutions and to careless boiling.

One objection to this wash is that it is decidedly "messy" to work with, and the man at the spray pump is certain to ruin his clothing and is fortunate if he keeps the spray from his eyes, thus causing serious inflammation. It is always advisable with this or any other spray to wear very old clothing that will never be used for any other purpose, and to protect the hands and face in some way. Automobile goggles would serve admirably to keep the spray from the eyes.

The Lime-Sulphur-Salt wash can only be used during the dormant period of the year, as it is fatal to foliage.

For summer use against the San .Jose and other scales, and against the myriad forms of plant lice that are every year becoming more and more common, there are several ways of using coal-oil effectively.

There are now being made certain kinds of spray pumps that automatically spray a mechanical mixture of coal oil and water 
by the use of compressed air. The oil and water are carried in separate tanks and are conveyed in separate lines of hose to the nozzle, where they are mixed.

Then there is the old and tried coal-oil emulsion, made by using any kind of strong soap to keep the oil from separating from the water. The emulsion has the advantage of staying on the affected parts of the plant for a longer time than the plain oil. Sometimes this is not to be desired, as the long application may result in foliage damage.

Careless spraving is worse than no spraying at all, for it not only fails of its object but it is expensive, and it may possibly result in actual damage to the tree. This is especially true in the case of the sprays used for the control of the scale inseets, and this department is in no way responsible for any damage that may result from the use of any spray, whether recommended in these pages or not. The best that we can do is to advise the use of sprays that have proved effective in other cases. Under changed conditions the results may be altogether different. Effective spraying is largely a matter of individual requirement and must be intelligently worked out for local conditions.

\section{SAN JOSE SCALE.}

(Aspidiotus perniciosus Comstock.)

So much has already been written relative to the danger arising from infection with San Jose scale that no argument is necessary to convince the average eitizen of the desirability of combating this pest with all the vignr that we can command. We will briefly review its important characteristics and, while it is not difficult to-reeognize, we will call attention to the fact that the genus "Aspidiotus" contains several other species that are very similar to the Aspidiotus perniciosus, and any of them may become very dangerous to plant life. Among these are the Putnam Scale (Aspidiotus ancylus Putnam). This is an insect so similar to the San Jose Scale that even the most expert sometimes confuse them. It has been claimed that the Putnam Scale does not become numerous enough to damage a tree. and this statement has led some entomologists to make the mistake of calling San Jose scales by another name simply because they were not thick on the tree. In general, it should be remembered, it makes but little difference what the scientific name of any insect is if 
it is assured that it is doing damage to vegetation, and any scale that shows signs of attaining considerable numbers should be treated exactly as you would treat a well-authenticated case of San Jose scale.

Life History.--The San Jose scale began life as a minute orange yellow insect, crawling freely about over the trunks and limbs of trees, whereupon its parent is attached. It is in this stage that the pest is most generally distributed by birds. It will crawl upon the feet and legs of the bird and be carried, possibly, great distances before again happening to erawl off on another tree.

This period of activity continues for, at most, a day or two, when the young seale settles down and begins to secrete the plate or seale proper which eements it firmly to the bark. It grows during the summer, feeding on the plant juices, which it draws through the bark with its probocis, and in early fall the eggs are fertilized in the body of the female by the winged male.

At the approach of winter the insect (still containing the halfgrown young) ceases feeding and becomes dormant, to resume feeding at the first sign of warm weather. Early in June the young attain their full size and emerge from the body of the parent, thus completing the life cycle. The production of young is continued throughout the season, two broods appearing, one in August and one early in October.

Adult Scale.-The adult scale appears as a small, rounded plate, grey in color, the center darker and elevated, the whole insect not more than one-sixteenth of an inch in diameter. On a badly-infested tree the scales will be so close together as to completely hide the bark, giving the branch an unhealthy, scurfy look.

\section{SCURFY SCALE.}

(Chionaspis furfurus_Fitch.)

While eommon and widely distributed, this scale has seldom become numerous enough to cause any material damage.

As will be seen by the illustration, the male and female differ considerably in form and size. At one stage in its life history the male is winged, as are the males of the majority of the seale insects. 
Under favorable conditions this scale may become destructive, and wherever they seem to be multiplying it would be advisable to use on them the same measures recommended for the San Jose Scale.

\section{COTTONY MIAPLE SCALE.}

(Pulvinaria innumerabilis Rathvon.)

During. the past two years the cottony maple scale has killed many trees in Indiana. It has not been confined to maples entirely, for trees of several other genera have been attacked and killed. Little or no attention has been paid to it in spite of its deadly character.

Life History.-After hibernating on the twigs of trees all winter, the female lays large quantities of eggs in May and June. It is at this season that the scale is most conspicuous, clinging to the under side of the twig and surrounded at one end with great masses of cottony padding, which is developed from the body simultaneously with the eggs. This eottony substance is persistent on the branches through the summer and until worn off with wind and rain.

The eggs hatch in a short time and the young at once migrate to the leaves, where they attach themselves in rows along the veins and begin feeding. They grow rapidly, and as summer advances the males and females are differentiated, the males developing wings. At the approach of fall the fertilized females attach themselves to the under sides of the twigs, where they remain all winter. The male dies at the end of the summer.

Treatment.-Winter spraying with Lime-Sulphur-Salt wash or with whale-oil soap is the best means of controlling the cottony scale.

On affected trees the leaves fall persistently throughout the season, often ending with the death of the tree. These leaves should be carefully raked up and burned, as they are an active source of infection for other trees.

Summer spraying would have to be very thorough to be effective, as every leaf on a badly affected tree is a host of innumerable scales. Sometimes a tree that has been completely stripped of its leaves and seemingly killed will put forth a new set of foliage in the fall, but it is not likely that such a tree could withstand the succeeding winter. 


\section{PLANT LICE. (Aphids.)}

There are many kinds of plant lice that affect eultivated plants. Almost all of them are dangerous and require prompt treatment. Many lice, such as the cherry and apple aphids, winter in the egg state, and the eggs are laid on the young twigs of the trees. In this way they may be distributed in nursery stock. The woolly apple louse forms a characteristic grayish cottony mass about it. It feeds on the apple and is one of the worst pests we have to deal with. Owing to the fact that one stage of the insect infests the roots of the trees, it is very difficult to treat, and a tree that is badly infested should be destroyed and the ground thoroughly dug up and exposed to the air. It will be safe to replant the same spot with another tree, but not with an apple. I have had partial success in treating this louse with carbon bisulphid, using an ounce of the liquid in each of several holes punched in the ground around the tree at a distance of about two feet from the trunk.

During the season of 1907 the common oat louse became so plentiful that many fields of oats were ruined. The only practical treatment so far suggested is to burn over the fields and thus reduce the number of individuals to affect next year's crop. The same field should not be planted in oats again without a rotation crop of clover or corn. The number of lice was due probably to the peculiar weather conditions of the preceeding spring. Accompanying the presence of the oat louse was a characteristic red rust that sometimes affects the grain regardless of the presence of any insect. Tice on the rose bushes sometimes become so numerous as to kill the tender growing tips or to destroy the foliage. In green houses it is a common practice to use tobacco smoke-in the open a strong. solution of tobacco made by boiling cheap clippings and stems will prove very effective if sprayed on the affected parts. For any of the lice this tobacco solution is a standard remedy. Where there is a large area to be treated the coal-oil emulsion will be found to be cheaper and perhaps more effective. 


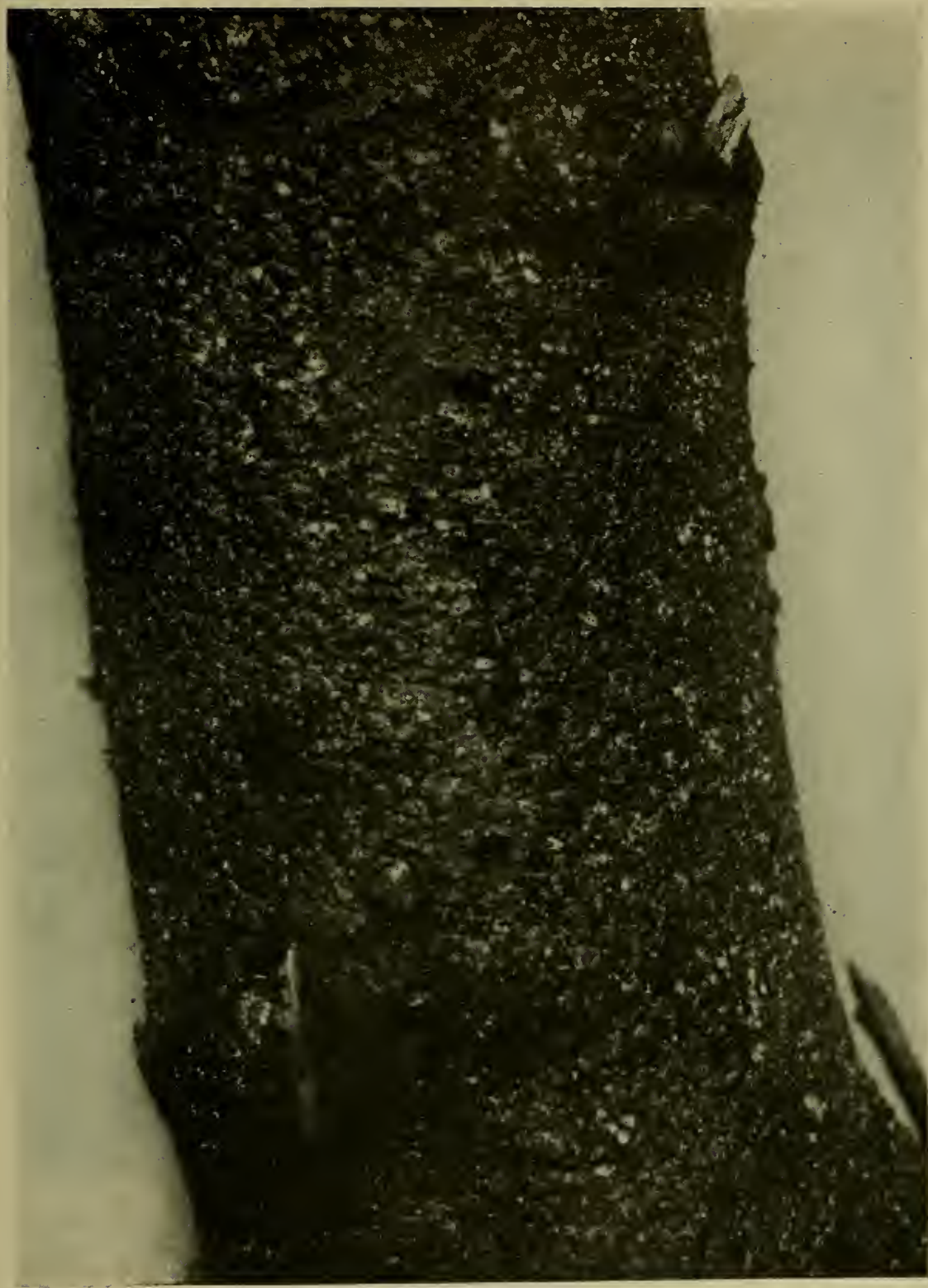

SAN JOSE SCALE. SLIGHTLY ENLARGED. 


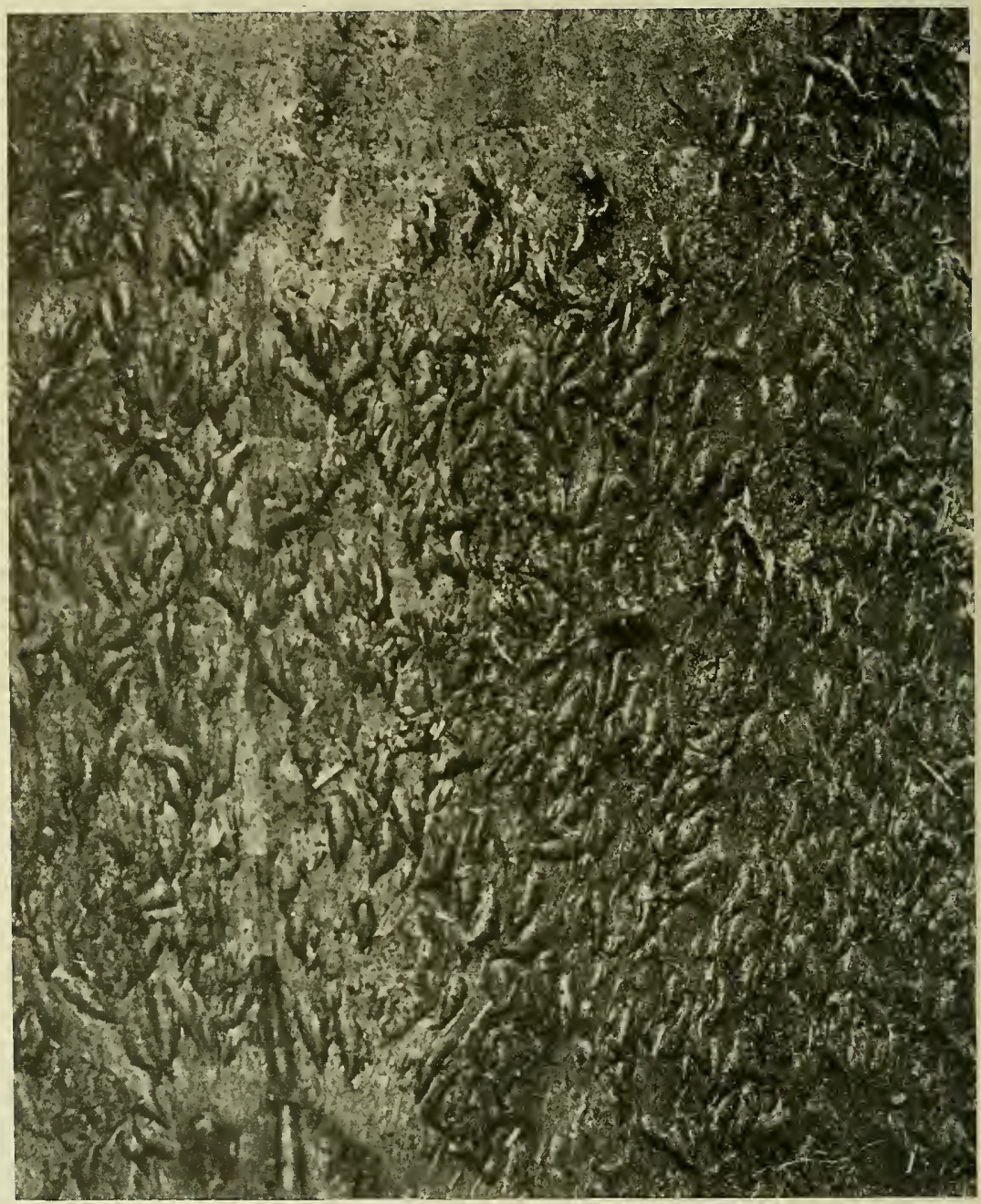

OYSTER SHELL SCALE. ENLARGED, WHERE IT BECOMES AS COMMON AS SHOWN IN THIS SPECIMEN THIS INSECT IS QUITE AS INJURIOUS AS THE SAN JOSE SCALE. 


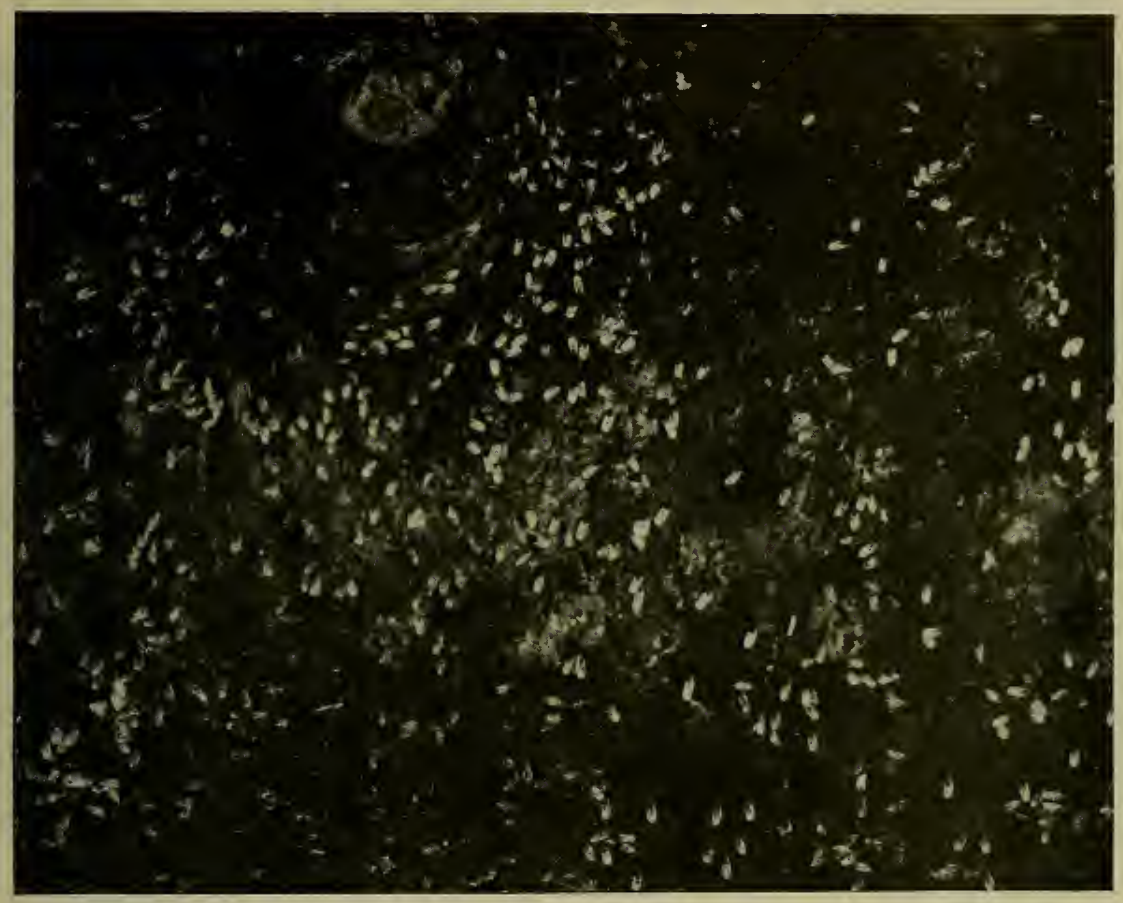

SCURFY SCALE. (MALE) SLIGHTLY ENLARGED. 


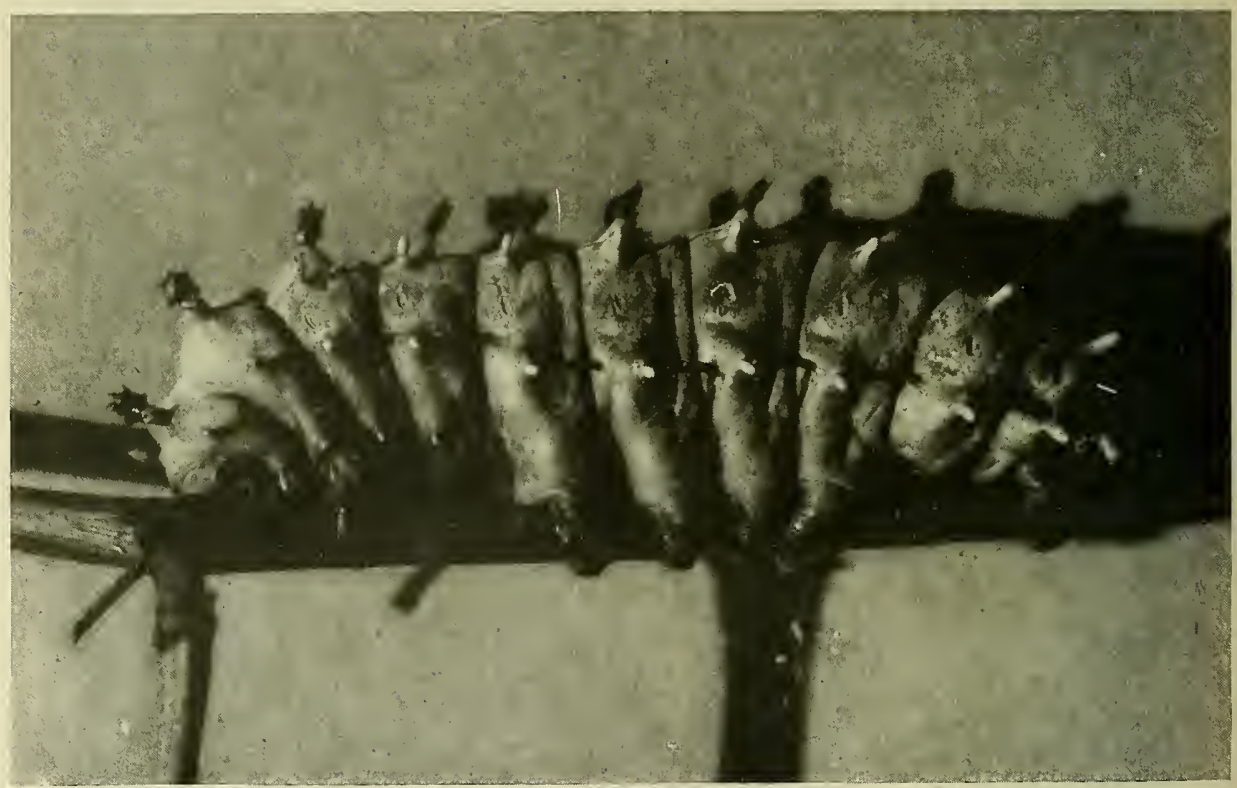

LARVA OF THE CECROPIA MOTH, A TYPICAL CHEWING INSECT. NATURAL SIZE. 


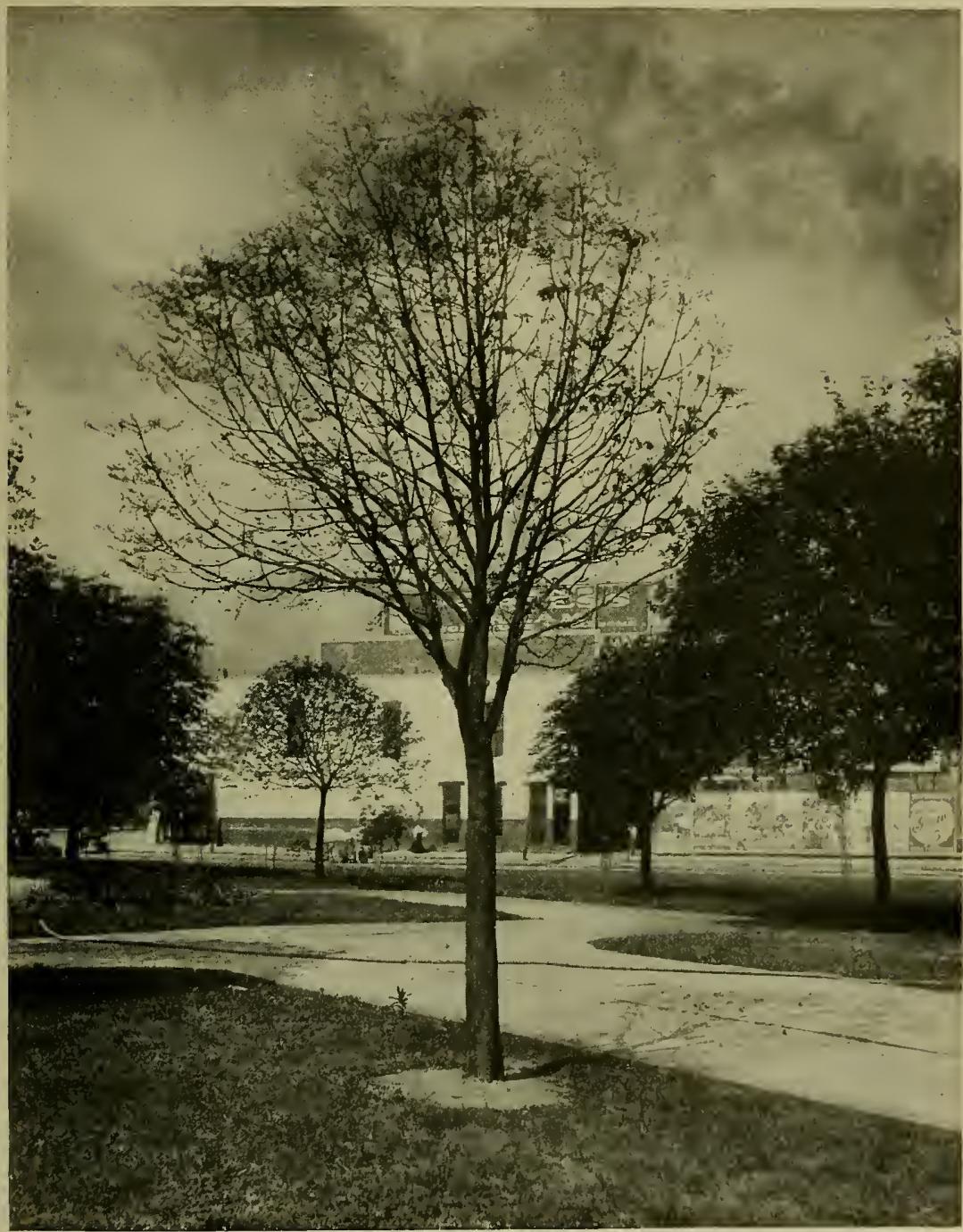

THE WORK OF THE TUSSOCK MOTH. 


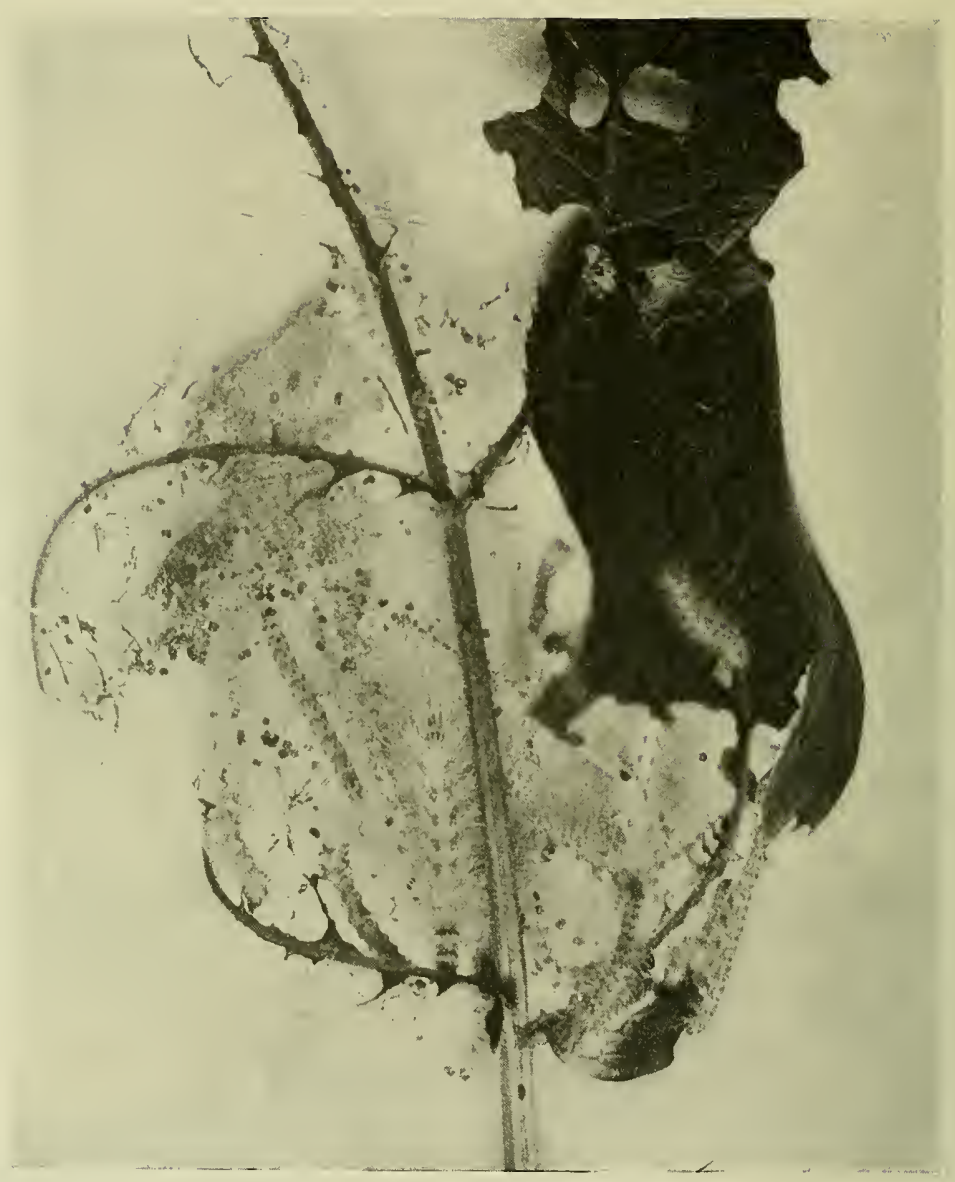

FALL WEB WORM AND ITS WORK. 


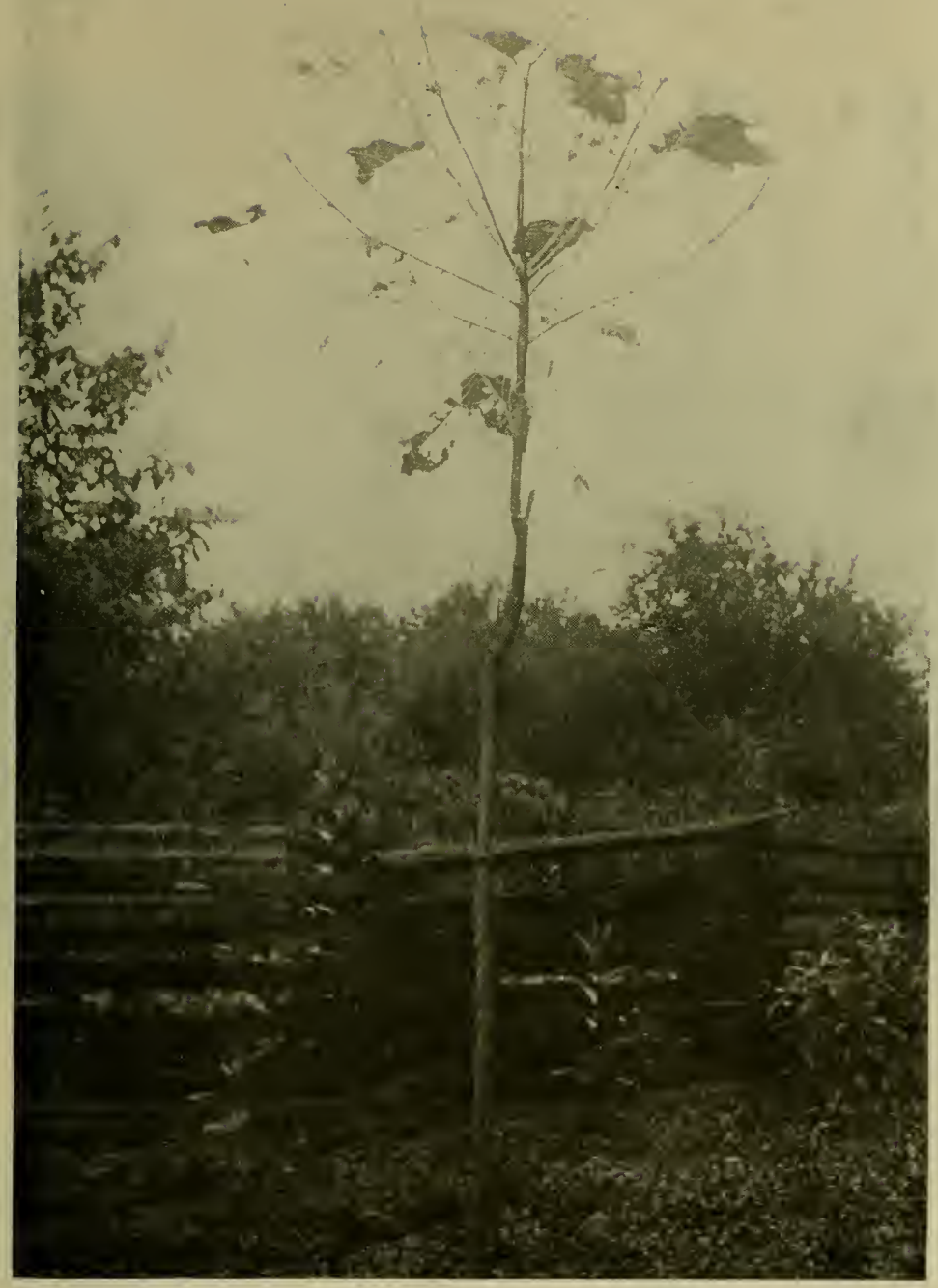

WORK OF THE CATALPA SPHINX MOTH. WHERE IT HAS MADE ITS APPEARANCE THIS INSECT HAS RENDERED CATALPA GROWING IMPOSSIBLE. 


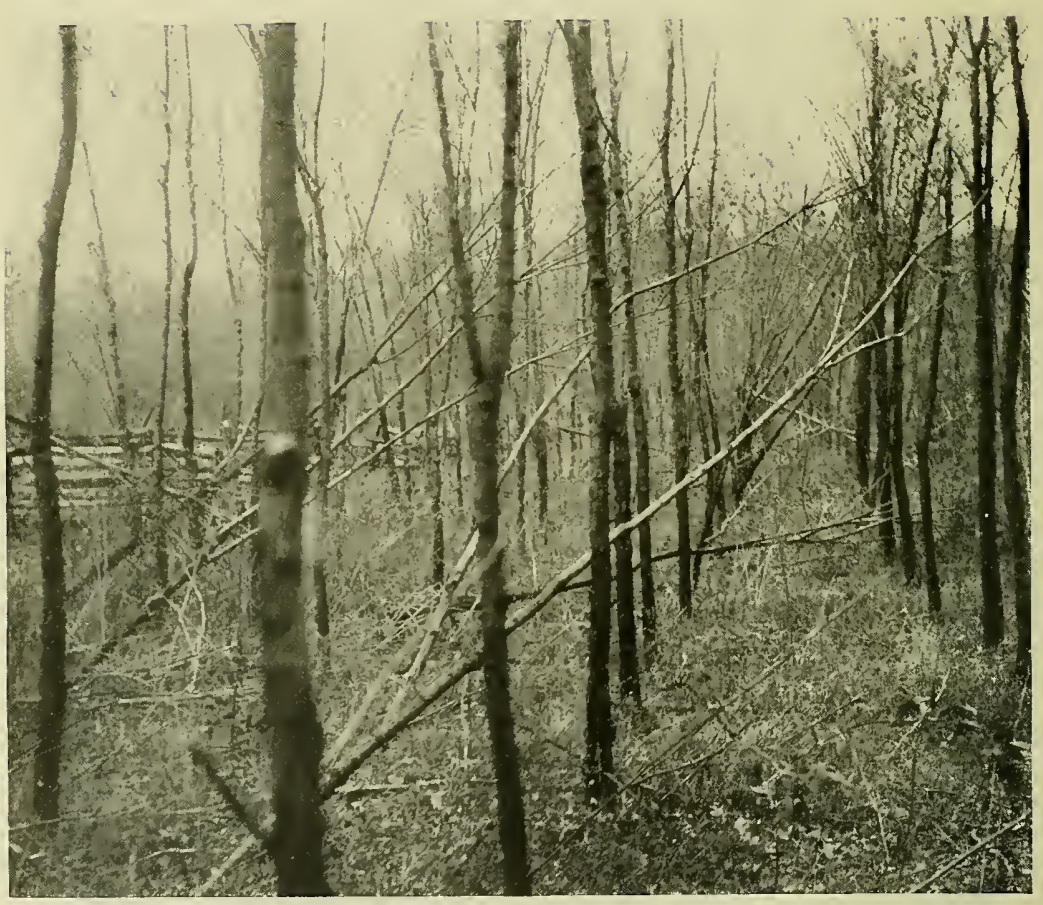

WORK OF THE LOCUST BORER. IN THIS PLANTATION TWENTY-SIX PER CENT. OF THE TREES HAVE BEEN EATEN OFF, AND ALL OF THE OTHERS ARE AFFECTED. 


\section{CODLING MOTH.}

It is the presence of this insect that makes apple growing difficult in this country. It is practically impossible to grow apples in Indiana without spraying and secure anything like perfect fruit. The insect hatches from the cocoons in the late spring and at once lays its eggs on the young apples, mostly at the flower end. The trees should be sprayed just after the blossoms fall so as to fill the calyx with the poison, as many of the young larva enter the fruit at this point. In case of very wet weather it is advisable to give a second spraying about two weeks later and again early in July. The late spraying is to meet a second brood of the insects that appear about that time. The first spraying may be of Paris Green or other arsenic poison, the subsequent ones with poisoned Bordeaux. Appendix A.

\section{CURCULIO.}

This is a small beetle that affects cherries, apples and plums -notably the last. The adult lays the eggs in a characteristic crescent-shaped slit in the young fruit, and hence they can not be reached by any poison, as they are completely covered by the fruit when they hatch. The adult beetles have a habit of feeding on the fruit, however, and some of them may be poisoned with a Paris Green spray applied just after the blossoms fall. It is also possible to gather the small beetles by jarring them down from the tree and catching them on sheets spread on the ground. Especially constructed "Curculio Catchers" are sometimes employed for this purpose and are made so that they may be moved from tree to tree. The insects are collected from the sheet and destroyed.

\section{LEAF EATERS.}

There is such a host of leaf eating insects that our space wili not permit a description of each species that can be found doing damage to Indiana erops. We will only mention some of the most common and destructive. Since the treatment for all of these insects is the same, it will not be difficult to handle any new problem that may present itself along this line. 


\section{TOMATO WORM (Sphinx Moth).}

This sometimes troublesome insect is the larval form of one of the Sphinx moths. The caterpillar is distinguished by the presence of a peculiar horn on the tail, which is commonly supposed to be venomous. As a matter of fact, it is absolutely without poison of any kind, and the worm can be handled with impunity by anyone. The insect passes the winter in the resting or pupal stage in the ground, and many of them will be destroyed by thorough cultivation. In small gardens where the worms are doing any considerable damage they may best be removed by hand picking. Large fields that are badly affected should be sprayed with Paris Green early in the season before the fruit attains any size. This will probably remove most of the brood and make the matter of hand picking the few that remain a comparatively easy task. Often this insect is attacked by a parasitic fly that lays its eggs on the body of the worm and eventually causes its death. The small cocoons of the fly are sometimes to be found sticking all over the bodies of the eaterpillars. Such specimens should be allowed to develop, as they are doomed to an early death, and by allowing the flies to reach maturity an additional control is placed over the remaining pests. Other forms of the Sphinx Mioth affect different plants. One of them is very destructive to tobaceo, and should be handled just as the tomato worm is handled.

\section{CATALPA SPHINX.}

Quite recently the so-called Catalpa Sphinx has been introduced into Indiana and is eausing great damage to the Catalpa Trees. It seems to be a very thrifty form and is one of the most difficult to control, owing to the character of the plants it feeds on. Neither spraying nor hand picking is practical, and the only method of control seems to be thorough cultivation under the trees in both late fall and early spring. Unless the insect can be exterminated in this way it will mean that Catalpa growing in forest plantations will soon be in the same condition as Black Locust growing, as the latter tree is thoroughly impractical because of the damage eaused by the uncontrollable locust borer. 


\section{SLUGS.}

These slimy larvae sometimes become very injurious on cherry and other trees. They can be destroyed with Paris Green or may be treated with common lime dusted on dry. Their sticky bodies hold the lime and they are quickly killed.

\section{POTATO BUGS.}

This insect is so common and so widely distributed that it does: not require any description. They may be gathered by hand and destroyed where they are not too thick. This is especially effective in the early part of the season, and will prevent serious devastation later in the summer. The standard spray, of course, is Paris Green.

\section{ELM LEAF BEETLE.}

\section{ELIM LEAF CATERPILIAR.}

Both of these troublesome insects are liable to be met with in almost any part of Indiana, and should be promptly treated. The damage is done by the larva of both insects and by the adult beetles as well. Paris Green sprayed on the trees when the pests make their first appearance is the only remedy worth considering.

\section{THE TUSSOCK MOTH.}

This troublesome insect is usually periodical in its attacks on trees, and is making its appearance in dangerous numbers for the first time in some years.

The moth winters in the egg state, and early in the summer the young larvae hateh and at once erawl to the foliage and begin to feed. The eggs are laid by the female moth on the old cocoons, and as these cocoons are frequently situated on houses and other objects away from the trees the young can be kept from the foliage by banding the trees with some sticky preparation which will keep them from crawling up the trunk. In the winter the cocoons bearing egg masses should be collected and burned so as to destroy all the young that are present. A favorite place for the situation of cocoons is under the overlapping weatherboards on the sides of houses. In summer, after the caterpillar's make their appearance, they can be destroyed by spraying the trees with 
Paris Green solution. This remedy is proving very successful in Indianapolis, but it must be thoronghly applied, and if washed off by the rain it should be repeated. The larva or caterpillar of this moth is one of the most beautiful of all the curious array of insects. It may be easily recognized by the presence of several tufts of white hair on the back, from which it takes its name of the Tussock Noth. At the head are two long pencils of brownish hair, with a single similar one on the tail. The front part of the head is bright red in color and a couple of red glands occupy segments near the tail. The hairs of this caterpillar are barbed, and sometimes cause more or less irritation to persons of tender skin when they are carelessly handled.

Suggestions given for the few forms enumerated above will suffice to give a key to the treatment required for almost any leafeating insects. Any special forms that may at any time cause damage should at once be sent to the office of the Entomologist for identification, and suggestions relative to their treatment will be sent promptly.

\section{BORING INSECTS.}

There are such a host of insects that clamage the trees by boring in their trunks or limbs that it is impossible to more than mention them in the short space that we have available in this report. One of the most destructive and important from an economic standpoint is the Locust Borer, an insect so common and so widely distributed that locust growing for fence posts is impractical over the greater part of eastern America. In Indiana I have yet to find a locality where the Locust Borer is not firmly established, and is already doing very great damage to the plantations that have been set out. There is no practical way of controlling this insect, and the only thing to do is to plant other trees that are not bothered in this way. Other borers affect the apple, peach and plum among our orchards, and to a certain extent they may be exterminated by cutting out and burning the affected trees. Where the cutting and burning is done thoroughly there is no reason why this treatment should not be successful. I know of an old peach orchard that was badly affected with the trunk borer when a friend of mine took possession of it. After three year's' work he has succeeded in exterminating the borer's, and most of the trees are completely recovered from their 
injuries and are in very fine shape today. Apple borers may sometimes be very successfully eut out without hurting the tree greatly. It would also be worth while to experiment with carbon bisulphid-pouring some of it into the channels made by the insects and covering the mouths of the burrows with putty to keep in the fumes. In France some successful experiments have been carried on by using a mixture of formaldehyde and glycerine in the same way as suggested for the carbon bisulphide.

In some parts of Indiana the Elm-tree Borer has done considerable damage, and wherever it makes its appearance it should be promptly attended to, as it rapidly spreads from one tree to another and in a short time a large area is worked over and destroyed.

- Numerous root borers affect different kinds of trees, and some of them may be gotten rid of by the liberal use of tobacco dust or wood ashes around the roots of the trees. Any of the potash salts are also valuable in this same connection, and even if they do not kill the borers they will so stimulate the tree that it may be able to outgrow the effects of the borer damage.

\section{FUNGUS DISEASES.}

In the control of fungus and bacterial diseases it must always be borne in mind that the trouble is usually transmitted in the form of very minute spores and any treatment must be thorough enough to kill all possible chances of any spores living through it. Often the body of the fungus plant itself is miscroseopic in size and the spores (which are to the fungus plant exactly as seeds are to the flowering plants) are infinitely small. In regard to many forms of fungal disease our knowledge is still very incomplete, but gradually we are finding new remedies for pests heretofore considered uncontrollable, and in the future we may expect great advances along the line of plant pathology. There are still some forms that do not yield to any treatment. In fact, it is not definitely known just what is the cause of certain plant diseases, and for lack of any remedy we ean simply use preventative measures and cut out and burn all affected plants. Peachyellow, Black-knot on the plum, Pear-blight, some of the root galls, and a number of other troubles come in this class on which scientists are still working. 


\section{APPLE (Anthracnose).}

This disease is caused by one of the fungi in the genus Gloeosporium, and causes small dark sunken spots in the fruit. It should be sprayed with Bordeaux both before and after blossoming.

\section{SOOTY FUNGUS.}

This fungus causes the fruit to appear speckled, as with a thin coat of soot or fly specks, and is caused by "Leptothyrium pomi," a minute fungus. 'The quality of the fruit is not injured but it is rendered less marketable. The spraying for Anthracnose will probably be all that is needed to prevent this disease.

\section{BLIGHT.}

The same bacteria that causes the blighting of pear is sometimes responsible for damage to the apple. Affected parts should be cut out and burned.

\section{APPLE SCAB.}

This is a disease that appears at its worst in cool, damp seasons, and at such times it is difficult to control. The fruit and foliage are both affected and as a result the standing crop is lost and the crop of the succeeding year prevented by a lack of leaf work. Early spraying with Bordeaux, as recommended above, should be effective for this trouble.

\section{BLACKBERRY (Orange Rust).}

This common disease of the Blackberry is best controlled by burning all the affected parts. It is transmitted by the red spores on the leaves in summer, and any treatment should be very thorough, or it will be time wasted.

\section{CHERRY (Black Knot. See Plum). SHOT-HOLE FUNGUS.}

This fungus affects the leaves of the cherry and causes them to become spotted. The spots later turn dark and fall out, giving the appearance of having been shot with a shot-gun. Dilute Bordeaux, early in the season, will prove effective. 


\section{CHERRY ROT.}

This is not a common disease in most parts of Indiana, but it may become very destructive. The fruit is affected and dries up, often remaining on the tree until the next season. These dried fruits are responsible for the fungus living over the winter, and as a means of prevention all affected fruit should be carefully gathered and destroyed. Bordeaux should be used before the blossoms are out.

\section{CUCUMBER (Anthracnose).}

Causes circular spots in the leaves to die. Also affects the stem. Bordeaux will be found effective if the trouble becomes serious.

\section{WILT.}

This is a disease of cucumbers, melons and squashes that is caused by the presence of a bacteria growing in the tissues of the plant. The water supply is eventually cut off and the vines die for lack of moisture. It is a very difficult thing to control and the only practical treatment is the extermination of the trouble by gathering and burning all affected vines.

\section{GRAPE.}

There is a long list of fungi that affects the grape, and for the most part our knowledge relative to their identification is not very definite. Most of them can be prevented by a thorough spraying with Bordeaux early in the spring before the buds open and again after the fruit has set.

\section{IMUSKMELON (See Cucumber).}

OATS.

Rust on the oats is rather common during the wet seasons. It is also usually associated with the presence of the green oat louse. As a rule it does not do any great damage. There is no practical remedy.

\section{SMUT.}

The smut of oats sometimes causes very serious losses and can be prevented by using the formalin treatment of the seed. Appendix (B). 


\section{PEACH.}

The crown gall of the peach and pear usually occurs at the root collar and takes on the form of a large excressence just below the surface of the ground. As yet we have had but few reports of it from Indiana, but conditions in other States indieate that it should be watched for and promptly gotten rid of. The only treatment is cutting out and burning.

\section{LEAF CURL.}

During cool, moist springs this trouble on the peach may become very serious. It ean be prevented by early spraying with Bordeaux before the buds open.

\section{PEACH YELLOWS.}

This is a serious disease of unlknown cause that must be treated by the removal and burning of all affected stock. It is characterized by the early ripening of the fruit, which is usually "off color" for the variety, excessive branching of the new shoots, and the production of bunches of slender, wiry twigs. The color of the foliage is also usually of a pale, sickly yellow color. It is one of the most dangerous diseases affecting the peach.

\section{PEAR BLIGHT.}

In this disease the branches wilt and the foliage turns dark but does not fall from the tree. It is caused by a specific bacteria and is contagious from one tree to another. It can be checked and eradicated by thoroughly eutting out and burning all affected parts.

\section{PLUM (Black Knot).}

This disease is caused by a fungus that infests the branches and causes unsightly excressences to form along them. It is contagious and destructive but can be controlled by cutting out the knots in the winter and burning them.

\section{SHOT-HOLE FUNGUS (See Cherry). RASPBERRY (Anthracnose).}

This fungus is sometimes so severe in its attacks on the raspberry that it renders its successful cultivation practically impossible. It oceurs on the young canes as round, purplish spots, and 
winters in the spore condition on the dead wood. Thorough cutting out of all affected stock and spraying the remainder well with Bordeaux would probably be effective in checking damage done by this pest. It is almost impossible to propagate young plants from stock that is affected with anthracnose, and nurseries affected with it will not be issued certificates.

\section{WHEAT RUST.}

This fungus (Puccinia Graminis) is difficult to control. In regions where it is very common wheat growers are trying to select varieties of wheat that are rust proof. There are no suggestions as to its control.

\section{STINKING SIMUT.}

This fungus trouble is sometimes very destructive to wheat, and can be prevented by the formalin treatmant as suggested for oat seed. Appendix (B).

\section{APPENDIX A.}

\section{BORDEAUX MIXTURE.}

Copper Sulphate .............. 6 pounds

Lime ................... 4 pounds

Water ................... 50 gallons

Dissolve the copper sulphate and the lime in. separate vessels, using a couple of gallons of hot water for each. When dissolved add the lime slowly to the copper solution and then put in enough water to make up the full fitty gallons.

Bordeaux Mixture is not an insceticide at all but is used as a preventative against fungus parasites. The copper acts by destroying the spores of the fungus, and the lime helps to make it stick on the tree. It is often valuable to add Paris Green to the Bordeaux and thus secure effective work against insects as well as against fungus. For this purpose the Bordeaux solution should be considered simply as so much water, and the proper quantity of Paris Green added as directed elsewhere in this bulletin. The excess of lime in the Bordeaux will be sufficient to veutralize the Paris Green. 


\section{APPENDIX B.}

\section{FORIMALIN TREATMENT.}

Formaldehyde is obtainable in what is known as a 40 per cent. solution. One pound of this solution should be diluted with 50 gallons of water and the grain well sprinkled with it. The seed should then be immediately covered with a wet sheet and allowed to remain for several hours. Allow to dry before planting.

For potato scab this same solution ean be used but should be diluted only half as much. Soak the potatoes for three hours before planting.

\section{APPENDIX C.}

\section{COAL OIL EIMULSION.}

The following formula for Kerosene Emulsion is from Prof. J. B. Smith's Economic Entomology:

$$
\begin{aligned}
& \text { Hard soap, shaved fine........... 1/2 pound } \\
& \text { Water ..................... } 1 \text { gallon } \\
& \text { Kerosene .................. } 2 \text { gallons }
\end{aligned}
$$

Dissolve the soap in boiling water; warm the kerosene and add the boiling hot suds to it; then churn with a force-pump for a few minutes and we get first a milky appearance, which yields rapidly to a cream, and this to a soft butter-like mass. When cold it will adhere to glass without oiliness, and the emulsion thus made, containing sixty-six per eent. of kerosene, will remain unchanged for some time, and may be mixed with water to any extent. Soft water must be used for best results, and with very hard water a real emulsion can not be obtained at all without the addition of borax sufficient to soften it. Diluted from nine to twelve times, this emulsion is very erfective against plant lice, many scale insects and such others as yield to contact insecticides in general. Plants vary in their resistance to this material, not only absolutely, but relatively under different elimatic conditions. Diluted nine times, few insects resist its effects and only the hardier plants can be safely treated; diluted fifteen times, only the green plant lice are affected, while some foliage shows material injury. Where plants do not readily stand a dilution of twelve times it is better not to use the emulsion at all. For winter use the emulsion is useless as against dormant scales, and more injurious to trees than the undiluted oil. 

